Article

\title{
The Influence of Partial Substitution of Malt with Unmalted Wheat in Grist on Quality Parameters of Lager Beer
}

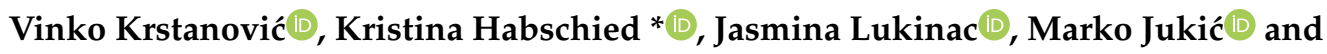 \\ Krešimir Mastanjević ${ }^{D}$ \\ Faculty of Food Technology Osijek, Josip Juraj Strossmayer University of Osijek, F. Kuhača 20, 31000 Osijek, \\ Croatia; vkrstano@ptfos.hr (V.K.); ptfosptfos2@gmail.com (J.L.); ptfosptfos@gmail.com (M.J.); \\ kmastanj@gmail.com (K.M.) \\ * Correspondence: khabschi@ptfos.hr; Tel.: +385-31-224-411
}

Received: 2 January 2020; Accepted: 28 January 2020; Published: 6 February 2020

check for updates

\begin{abstract}
The aim of this research was to assess whether the grist mixture (50\% malt, 34\% maize grits, and $16 \%$ unmalted wheat) used for the production of beer 1 could be appropriate for lager to retain the declared quality and colloidal stability during the commercial shelf life (6 months) in regards to beer 2 produced completely out of barley malt. Raw materials, worts, and beers were analyzed before and after production and over the period of 6-month storage. All analyses were done in accordance with the European Brewery Convention methods. Beer 1 resulted in a more desirable wort composition considering the total, high molecular weight (HMW) proteins, and viscosity. Beer 1 had less total proteins and polyphenols, lower viscosity and color, and higher starting clarity than beer 2 . Haze measurements showed that even though beer 1 had lower starting haze, it resulted in significantly less colloidal stability during the storage of 6 months, in comparison to beer 2 . The results indicate that the production of light lager beer using unmalted wheat in grist could be acceptable for colloidal stability only if such beer is to be stabilized by operations that ensure the removal of haze inducers (primarily haze active proteins).
\end{abstract}

Keywords: wheat; light lager beer quality; colloidal stability; commercial shelf life

\section{Introduction}

Minimum shelf life or commercial shelf life (CSL) of beer is a time period during which the beer retains its taste, color, clarity, foam stability, and other sensory characteristics [1]. CSL for lager beers, the most popular beer type, can be 3-12 months, but it is usually declared as 6 months. The basic condition to ensure the CSL is the colloidal stability of beer that can be defined as "the time during which the brightness of a beer remains as good as it did when it was first packaged" [2]. Colloidal stability manipulations are done to ensure the quality of packaged beer during the shelving time and to bring the technical shelf life (TSL) close to the CSL. In practice, due to the economic reasons, the TSL is somewhat longer than CSL, so the lager beer consumer can expect beer to keep its visual characteristics under specified storage conditions (for instance at $20^{\circ} \mathrm{C}$ ) during the whole CSL period. For lagers produced only from malt, or malt and malt adjuncts favorable for CSL (corn grits), the CSL insurance is easy with respect to common good practice in the manufacturing process. When producing lagers that are composed of commodities who can be problematic for colloidal stability it is absolutely necessary to investigate, throughout the whole production process and during the CSL period, their influence on the final beer. One such commodity is unmalted wheat. Even though it is rarely used in lager beer production, it can be applied as an adjunct. Some breweries still produce the 
popular lager beer whose grist is comprised of 50\% malt, 34\% corn grits, and $16 \%$ unmalted wheat. This grist composition results in lagers characterized by lighter color, and attractive and stable foam. Due to the absence of appropriate wheat varieties for brewing, bread varieties are usually used as adjuncts. Hard, red, winter wheat varieties are appropriate due to the weaker gluten index values, lower protein share, and higher extract values which usually result in lighter beer color. Although the wheat malt is characterized by a more pronounced aroma, the use of unmalted wheat also contributes to the aroma of "neutral type of beer" giving it a specific, refreshing taste [3]. The use of unmalted wheat results in a lower $\mathrm{pH}$ of beer, due to a reduced buffering potential and a lighter beer color, caused by the absence of a kilning process. A further characteristic of usage of unmalted wheat in grist is the final beer with a more attractive and stable foam due to the wheat proteins. Wheat proteins related to the improved foam characteristics of wheat beers are wheat's glycoproteins [4]. Foam stability depends on high molecular weight wheat non-starch polysaccharides, arabinoxylans. They contribute to the beer viscosity and are prone to reduce the liquid drainage from foam, which results in increased foam stability [5]. Furthermore, Kakui et al. [6] reported that the bubble size of wheat beer is much smaller than that of barley beer, which makes the wheat beer foam creamier. When using the winter, red, hard wheat varieties an increased value of higher molecular weight (HMW) proteins that cause haze can be expected, even in cases when wheat contains higher protein share than barley malt. This is because wheat naturally contains a higher share of the higher molecular weight proteins that can cause haze [7]. In bright beers (pilsner, lager), the formation of haze is a serious quality problem and limits the storage life of the final product. The major colloidal haze components in lagers and pilsners are proteins conjoined with polyphenols and starch or degraded starch [8,9]. The influence of unmalted wheat on the final beer quality is mostly well-studied thanks to the research done on Belgian and German white beers [4,9]. HMW wheat proteins are rich with proline and are precursors of haze, or "haze active" proteins [10-12]. Due to the limited hydrolysis of wheat proteins by barley malt proteolytic enzymes, the use of unmalted wheat as an adjunct, results in FAN (free amino nitrogen) dilution $[13,14]$. Since yeast growth and metabolism (and subsequently fermentability) greatly depend on FAN content in the wort, beer's flavor profile is closely related to the formation of higher alcohol and esters during fermentation and the maturation phase. FAN also affects the emergence of off-flavor components, diacetyl, and dimethylsulphide $[4,13]$. The addition of unmalted wheat into the grist is followed by beer's colloidal stability reduction which represents a problem since beer is transported and stored for a longer period of time.

For that reason, it was important to investigate several issues: (1) if the grist content is optimal regarding the share of unmalted wheat for beer to retain the characteristic lager quality; (2) can such beer retain the declared quality during a 6-month CSL. In order to obtain the wanted results, analysis of raw commodities, industrial worts, and obtained beers was conducted immediately after production and during storage for 6 months at room temperature. During this period, lager's quality indicators were compared to a lager type beer (all barley malt) produced by the same production, in the same factory. While analyzing the colloidal stability of these beers a highly colloidal stable beer was used as a reference.

\section{Materials and Methods}

\subsection{Beer Sample Production}

The investigated beer was obtained as a standard product from a conventional lager brewery (Osijek, Croatia), brewed from a barley malt and maize mixed-grist by classic double decoction mashing procedure. Two batches were produced for both beers. The grist for beer 1 was composed of malt (50\%): unmalted wheat (16\%): maize grist (34\%). Beer 2 was all-malt grist. The water hardness for the production of beer 1 was $3.7^{\circ} \mathrm{DH}$, and for beer 2 it was $3.1^{\circ} \mathrm{DH}$. Grist mass was $5000 \mathrm{~kg}$, mashing-in water for beer 1 was $179 \mathrm{hL}$, and for beer $2180 \mathrm{hL}$. Barley malt and unmalted wheat were mashed together with the addition of Ceramix $2 X \mathrm{~L}$, during the protein rest $50-55^{\circ} \mathrm{C} / 60 \mathrm{~min}$, while the maize 
grits were mashed separately in $44 \mathrm{hL}$ of water with Termamyl $120 \mathrm{~L}$ and $10 \%$ malt mash. After the first decoction mashing was finished, malt mash and maize mash got combined and mashing was continued until the second decoction was separated (1/3 of the volume). The second decoction was mashed for $10 \mathrm{~min}$. After that, it was again combined with the main mash. Beer 2 was also produced with the classic double decoction mashing procedure. Sweet wort (original gravity $=12{ }^{\circ} \mathrm{P}$ ) was boiled with hop pellets and hop extract, and the hopped wort was fermented using Saccharomyces pastorianus var. carlsbergensis in a cylindro-conical vessel at $12{ }^{\circ} \mathrm{C}$ (main fermentation) for 5 days (beer 1) and 10 days for beer 2 . Fermented beer was chilled and stored at $1{ }^{\circ} \mathrm{C}$ for 21 days. Beer was then subjected to final unit operations: filtration with kieselguhr, followed by trap filtration, pasteurization $\left(70^{\circ} \mathrm{C} / 30^{\prime \prime}\right)$, and filling into brown glass bottles. During the whole production process, from the admittance of raw materials to the final beer, the production of both beers was tracked and monitored. Samples were stored at constant temperature $\left(20^{\circ} \mathrm{C}\right)$ in a storage facility belonging to the brewery. Sampling was conducted in accordance with the internal brewery documents. Samples of both beers were taken point-blank after the production and stored for 6 months, a time period declared as CSL. Samples were taken in triplicate and analyzed each month. The referent beer was subjected to additional stabilization with PVPP (polivinylpolypyrolidone).

\subsection{Analysis of Raw Materials, Worts, and Finished Beers}

Analyses of quality indicators of raw materials, worts, and finished beers were done according to EBC (European Brewery Convention) [15] and MEBAK (Middle European Brewing Analysis) [16]. Microbiological analysis of beer 1 and beer 2 resulted in no saprophytic microorganisms for both beers. Colloidal stability was monitored as the increase of haze (EBC units) and it was measured in final beers before and after beer "force-aging" [15].

Beer analysis regarding the induction of haze via tannic acid (Fluka 7240-53-7 EC No 2766380) and gliadin (Sigma 900-90-3 EEC No 232-707-7) was conducted according to Sibert [17,18]. In short, the haze was induced by adding tannic acid (stock solution) to the tested beers. Samples were degassed and incubated for $30 \mathrm{~min}$ in a water bath at $25^{\circ} \mathrm{C}$ for tannic acid and $80^{\circ} \mathrm{C}$ for gliadin. Samples treated at $80^{\circ} \mathrm{C}$ were then placed in a $25^{\circ} \mathrm{C}$ bath for attemperation before haze measurement. As a control, gliadin and tannic acid were combined in $0.02 \mathrm{M}, \mathrm{pH} 4.2$ phosphate buffer in a beaker. The mixture $(200 \mathrm{~mL}$ in a $300 \mathrm{~mL}$ beaker) was held in a water bath at 25 or $80^{\circ} \mathrm{C}$ for $30 \mathrm{~min}$. The $80^{\circ} \mathrm{C}$ treated samples were then placed in a $25^{\circ} \mathrm{C}$ bath for attemperation before haze measurement. Light scattering measurements were carried out with an HZ013 lg-automatic, according to the manufacturer's instructions. Results were expressed in EBC turbidity units.

Colloidal stability was measured at $0,1,3$, and 6 months after production and was done in comparison to the referent light lager. The analyses were conducted at the Slovenian Institute of Hop Research and Brewing, Žalec, Slovenia. Analysis of colloidal stability of beer 1 and beer 2 immediately after production and during storage, as well as the beers' resistance toward haze induction with tannic acid and gliadin, was conducted in Carlberg brewery laboratory, Croatia.

\subsection{Statistical Analysis}

Data analysis: differences between the average values of the raw materials, micromalting, and finished malt quality indicators were analyzed using the analysis of variance (ANOVA) and Fisher's least significant difference (LSD) test, with statistical significance being set at $p<0.05$. The same parameters were subjected to correlation analysis (Pearson's correlation test) so as to determine their possible statistically meaningful relationships with the colloidal stability of beer. Statistical analysis was carried out using Statistica Ver. 8.0 StatSoft Inc. Tulsa, OK, USA.

\section{Results and Discussion}

The aim of this research was to assess whether the grist mixture (50\% malt, $34 \%$ maize grits, and $16 \%$ unmalted wheat) used for beer 1 could be appropriate for lager to retain the declared quality 
and colloidal stability during the recommended CSL (6 months). The intention of the raw material analysis shown in Table 1 is to give an insight into the colloidal stability components, such as proteins $(40 \%-75 \%)$, polyphenols (in combination with proteins), and carbohydrates $(2 \%-15 \%)$. The formation of haze is affected by several other factors and components: residual starch, pentosanes (wheat), oxalate (calcium-deficient worts), $\beta$-glucans (inadequately modified malt), carbohydrate, and protein (autolyzed yeast cells), lubricants from can lids and dead bacteria from malt [19]. The grist mixture used for beer 1 was to ensure a certain dilution of wheat proteins considering wheat contains more HMW (high molecular weight) proteins, which do not undergo degradation during the brewing process [7]. The results for malt show that the used malt was light malt of standard quality (satisfactory total and soluble protein share) with a somewhat higher HMW protein share $(>25 \%)$. As mentioned before, these proteins are, alongside the haze active (HA) polyphenols, an important factor in haze formation [20].

Table 1. Basic raw material quality indicators used for the production of beer 1 and beer 2 .

\begin{tabular}{|c|c|c|c|}
\hline Indicator & Wheat & Corn Grits & Malt \\
\hline 1000 grain weight (g dm) & $32.7 \pm 0.2$ & - & $33.2 \pm 0.6$ \\
\hline Friability (\%) & - & - & $81 \pm 0.5$ \\
\hline Vitreosity (\%) & $24 \pm 0.8$ & - & $8 \pm 0.5$ \\
\hline NIR-HD grain hardness & $56 \pm 0.2$ & - & - \\
\hline Total proteins $(\% \mathrm{dm})$ & $12.71 \pm 0.03$ & $8.37 \pm 0.01$ & $10.80 \pm 0.02$ \\
\hline Total N (\% dm) & $2.03 \pm 0.07$ & $1.33 \pm 0.02$ & $1.67 \pm 0.01$ \\
\hline Total pentosans (\% dm) & $7.11 \pm 0.12$ & - & - \\
\hline Soluble pentosans (\% dm) & $0.68 \pm 0.02$ & - & - \\
\hline Fine extract $(\% \mathrm{dm})$ & $78.39 \pm 0.21$ & $68.75 \pm 0.11$ & $83.00 \pm 0.19$ \\
\hline $\begin{array}{l}\text { Fine extract, enzyme method Termamyl } \\
\text { 120L (\% dm) }\end{array}$ & $80.37 \pm 0.02$ & $82.14 \pm 0.03$ & - \\
\hline Viscosity (mPas $8.6 \%)$ & $1.362 \pm 0.021$ & $1.650 \pm 0.022$ & $1.713 \pm 0.081$ \\
\hline Lautering time (min) & $60 \pm 2$ & $71 \pm 2$ & $30 \pm 10$ \\
\hline Saccharification time (min) & $45 \pm 5$ & $55 \pm 3$ & $19 \pm 2$ \\
\hline $\mathrm{pH}$ of $\mathrm{mash} /$ wort & $6.38 \pm 0.08$ & $6.24 \pm 0.05$ & $5.98 \pm 0.02$ \\
\hline Final attenuation of mash/wort (\%) & $89.8 \pm 0.03$ & - & $84.6 \pm 0.01$ \\
\hline Soluble $N^{*}(g / 100$ g dm $)$ & $0.36 \pm 0.09$ & $0.17 \pm 0.07$ & $0.73 \pm 0.01$ \\
\hline $\mathrm{HMW}^{* *} \mathrm{~N}(\mathrm{~g} / 100 \mathrm{~g} \mathrm{dm})$ & $0.21 \pm 0.06$ & $0.08 \pm 0.00$ & $0.20 \pm 0.02$ \\
\hline HMW $^{* *} \mathrm{~N} /$ soluble N (\%) & $59.9 \pm 0.2$ & $46.7 \pm 0.4$ & $27.4 \pm 0.1$ \\
\hline $\mathrm{MMW}^{* * *} \mathrm{~N}(\mathrm{~g} / 100 \mathrm{~g} \mathrm{dm})$ & $0.05 \pm 0.11$ & - & $0.11 \pm 0.31$ \\
\hline $\mathrm{LMW}^{* * * *} \mathrm{~N}(\mathrm{~g} / 100 \mathrm{~g} \mathrm{dm})$ & $0.10 \pm 0.07$ & $0.09 \pm 0.01$ & $0.42 \pm 0.05$ \\
\hline Formol N (mg/g dm) & $23 \pm 0.8$ & - & $121 \pm 0.5$ \\
\hline FAN (mg/100 g dm) & $30.3 \pm 0.1$ & - & $189.1 \pm 0.2$ \\
\hline Total lipids (\% dm) & - & $3.95 \pm 0.03$ & - \\
\hline Total polyphenols $(\mathrm{mg} / \mathrm{L})$ & $18.86 \pm 0.03$ & $41.33 \pm 0.02$ & $53.64 \pm 0.01$ \\
\hline Anthocyanogens (mg/L) & - & - & $12.06 \pm 0.02$ \\
\hline Polymerization index & - & - & $4.45 \pm 0.01$ \\
\hline
\end{tabular}

Values are means $\pm \mathrm{SD}$ of three measurements; $\mathrm{dm}$-dry matter; $\mathrm{N}^{*}$-nitrogen; $\mathrm{HMW}^{* *}$-high molecular weight;

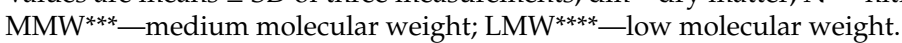

Total polyphenols in malt were below the recommended limit $(60-110 \mathrm{mg} / \mathrm{L})$, and anthocyanogens were close to the lower limit for light malt (13-34 mg/L). The polymerization index was closer to the upper limit for this malt type. The used malt had good extract, friability, FAN, and filterability values. The used wheat showed increased values for virtuosity, but its character was mostly temporary, a common trait for domestic varieties [21]. The share of pentosanes was mostly average. Only about $10 \%$ of total pentosanes were soluble. According to $\mathrm{Lu}$ [22] only a high-molecular fraction of pentosanes causes problems in brewing. Wheat mash has significantly higher final attenuation in regard to malt wort. The concentration of total polyphenols in wheat was significantly lower in comparison to malt. Several authors consider that the dilution of polyphenols by adding unmalted wheat as a part of the mash, leads to the increased colloidal stability, due to the fact that wheat contains no haze-active polyphenols and adds less protein to the wort than barley malt [23-25]. However, a combination of 
wheat with maize grits actually results in increased total polyphenols since maize is much richer in polyphenols than wheat [26].

This can be seen from Table 2 where values for beer 1 show higher values than for beer 2 . A similar relationship can be noticed for anthocyanogenes, the most active low molecular weight polyphenols [20]. Furthermore, a lower viscosity in the wort 1 was reported. This can be attributed to the low wheat protein and pentosanes' solubility. Namely, wheat proteins and pentosanes are not as soluble as malts. The North European wheat varieties have more soluble proteins and pentosanes than the ones of domestic assortment [27]. Total $\mathrm{N}$ for wort 1 was much lower in regard to wort 2, while values for HMW N were similar. Considering that only $16 \%$ of wheat was added to grist, and that maize grist does not affect the HMW protein fraction, this shows that the wheat is a source of the increased HMW N, a precursor of HA proteins. The high share of maize grits did not allow the polyphenols' dilution, thus the increased share of HMW proteins can affect and reduce the colloidal stability of beer. Furthermore, the shares of medium MMW N and LMW N fractions was significantly lower in wort 1 than in wort 2 . This resulted in lower acidity of wort 1 (higher $\mathrm{pH}$ ). Some authors reported that the use of unmalted cereals such as wheat might result in a lower beer $\mathrm{pH}$ (due to a reduced buffering potential) and a paler beer (no kilning process) [4].

Table 2. Values of the main quality indicators of industrial worts of beer 1 and beer 2 .

\begin{tabular}{ccc}
\hline Indicator & Wort 1 & Wort 2 \\
\hline Specific gravity of wort $\left(\mathrm{g} / \mathrm{cm}^{3}\right)$ & $1.0487 \pm 0.0002^{\mathrm{a}}$ & $1.0491 \pm 0.0001^{\mathrm{a}}$ \\
Original extract in wort $(\% \mathrm{dm})$ & $11.93 \pm 0.23^{\mathrm{a}}$ & $11.83 \pm 0.31^{\mathrm{b}}$ \\
Viscosity (mPas) & $1.77 \pm 0.03^{\mathrm{b}}$ & $2.10 \pm 0.01^{\mathrm{a}}$ \\
pH of wort & $5.73 \pm 0.08^{\mathrm{a}}$ & $5.12 \pm 0.07^{\mathrm{b}}$ \\
Total N* $(\mathrm{mg} / \mathrm{L})$ & $880.2 \pm 0.1^{\mathrm{b}}$ & $1027.2^{\mathrm{b}} \pm .1^{\mathrm{a}}$ \\
$\mathrm{HMW}^{* *} \mathrm{~N}(\mathrm{mg} / \mathrm{L})$ & $240.6 \pm 0.1^{\mathrm{b}}$ & $263.4 \pm 0.3^{\mathrm{a}}$ \\
$\mathrm{HW}^{* *} \mathrm{~N} / \mathrm{soluble} \mathrm{N}(\%)$ & $27.3 \pm 0.2^{\mathrm{a}}$ & $25.6 \pm 0.3^{\mathrm{b}}$ \\
MMW $^{* * *} \mathrm{~N}(\mathrm{mg} / \mathrm{L})$ & $51.6 \pm 0.4^{\mathrm{b}}$ & $82.7 \pm 0.5^{\mathrm{a}}$ \\
LMW $^{* * * *} \mathrm{~N}(\mathrm{mg} / \mathrm{L})$ & $588.0 \pm 0.7^{\mathrm{b}}$ & $681.1 \pm 0.5^{\mathrm{a}}$ \\
Brewhouse yield $(\%)$ & $70.54 \pm 0.64^{\mathrm{b}}$ & $71.55 \pm 0.34^{\mathrm{a}}$ \\
Bitterness $(\mathrm{EBC}$ unit) & $30.2 \pm 0.1^{\mathrm{a}}$ & $28.3 \pm 0.7^{\mathrm{b}}$ \\
Clarity (\% transparency) & $34.2 \pm 0.4^{\mathrm{a}}$ & $22.2 \pm 0.1^{\mathrm{b}}$ \\
Color (EBC unit) & $7.90 \pm 0.23^{\mathrm{b}}$ & $8.4 \pm 0.12^{\mathrm{a}}$ \\
\hline
\end{tabular}

Values are means \pm SD of three measurements and values with different letters $\left(^{\mathrm{a}, \mathrm{b}}\right)$ in a row are statistically different; $\mathrm{dm}$-dry matter; $\mathrm{N}^{*}$ —nitrogen; $\mathrm{HMW}^{* *}$ —high molecular weight; $\mathrm{MMW}^{* * *}$ —-medium molecular weight; $\mathrm{LMW}^{* * * *}$ - low molecular weight.

Table 3 shows the results of finished beers, just after the filling into bottles. The results for both beers are satisfactory considering the basic pale lager quality indicators. Beer 1 showed better values for clarity (almost brilliant) and viscosity, but lower color, $\mathrm{pH}$, and foam stability in comparison to beer 2. The extract was a bit lower in beer 1, while the alcohol concentration was higher probably due to the fact that beer 2 was subjected to lower temperature during fermentation (real attenuation limit for beer 1 was significantly higher than for beer 2). Beer 1 showed lower values for color than beer 2, but this can be attributed to the fact that the use of adjuncts such as maize and wheat, commonly results in lighter color beers [28]. $\mathrm{pH}$ values for both beers were within the recommended limits, although a lower $\mathrm{pH}$ was expected in beer 2 (due to the significantly higher amounts of LMW N in wort 2 (Table 2) and FAN values in malt (Table 1) who react with sugars and give an acid reaction). Viscosity values for both beers were below the lower limit for beer $1.78 \mathrm{mPas}$. Wort viscosity for beer 1 was significantly lower than the viscosity for beer 2, but they were both within the limitation for this type of beer [29]. 
Table 3. Quality indicators of beer 1 and beer 2 filled in bottles.

\begin{tabular}{|c|c|c|}
\hline Indicator & Beer 1 & Beer 2 \\
\hline Specific gravity $\left(\mathrm{g} / \mathrm{cm}^{3}\right)$ & $1.0081 \pm 0.0003^{\mathrm{a}}$ & $1.0071 \pm 0.0002^{a}$ \\
\hline Original extract $(\% \mathrm{dm})$ & $11.96 \pm 0.02^{b}$ & $12.16 \pm 0.08^{a}$ \\
\hline Apparent attenuation (\%) & $85.0 \pm 0.5^{\mathrm{a}}$ & $81.1 \pm 0.1^{b}$ \\
\hline Real attenuation (\%) & $68.9 \pm 0.1^{a}$ & $65.8 \pm 0.3^{b}$ \\
\hline Viscosity (mPas) & $1.513(1.516) * a$ & $1.507(1.486) * a$ \\
\hline $\mathrm{pH}$ & $4.31 \pm 0.03^{\mathrm{b}}$ & $4.48 \pm 0.01^{\mathrm{a}}$ \\
\hline $\mathrm{rH}$ & $9.036 \pm 0.011^{b}$ & $9.225 \pm 0.002^{\mathrm{a}}$ \\
\hline Clarity (EBC unit) & $0.38 \pm 0.01^{\mathrm{a}}$ & $0.42 \pm 0.02^{\mathrm{a}}$ \\
\hline Color (EBC unit) & $6.28 \pm 0.04^{b}$ & $7.45 \pm 0.03^{a}$ \\
\hline Bitterness (EBC unit) & $23.10 \pm 0.11^{\mathrm{a}}$ & $19.75 \pm 0.12^{b}$ \\
\hline Vicinal diketones (mg/L) & $1.020 \pm 0.003^{a}$ & $0.072 \pm 0.001^{b}$ \\
\hline Foam stability (s) & $75.6 \pm 0.2^{b}$ & $91.0 \pm 0.4^{\mathrm{a}}$ \\
\hline Total $N^{*}(\mathrm{mg} / \mathrm{L})$ & $745.5 \pm 0.2^{b}$ & $850.2 \pm 0.3^{a}$ \\
\hline $\mathrm{HMW}^{* *} \mathrm{~N}(\mathrm{mg} / \mathrm{L})$ & $216.1 \pm 0.1^{\mathrm{a}}$ & $198.2 \pm 0.2^{b}$ \\
\hline $\mathrm{HMW}^{* *} \mathrm{~N} /$ soluble $\mathrm{N}(\%)$ & $29.0 \pm 0.2^{a}$ & $23.3 \pm 0.3^{b}$ \\
\hline $\mathrm{MMW}^{* * *} \mathrm{~N}(\mathrm{mg} / \mathrm{L})$ & $127.6 \pm 0.1^{b}$ & $155.4 \pm 0.2^{\mathrm{a}}$ \\
\hline $\mathrm{LMW}^{* * * *} \mathrm{~N}(\mathrm{mg} / \mathrm{L})$ & $401.8 \pm 0.5^{b}$ & $496.9 \pm 0.9^{a}$ \\
\hline Total polyphenols (mg/L) & $62.90 \pm 0.76^{b}$ & $71.04 \pm 0.65^{\mathrm{a}}$ \\
\hline Anthocyanogens (mg/L) & $25.68 \pm 0.23^{a}$ & $22.97 \pm 0.12^{b}$ \\
\hline Polymerization index & $2.45 \pm 0.11^{b}$ & $3.09 \pm 0.09^{a}$ \\
\hline Dissolved oxygen (mg/L) & $0.21 \pm 0.09^{\mathrm{a}}$ & $0.16 \pm 0.01^{b}$ \\
\hline Concentr. of $\mathrm{CO}_{2}(\mathrm{mg} / \mathrm{L})$ & $5.13 \pm 0.02^{b}$ & $5.70 \pm 0.09^{a}$ \\
\hline Concentr. $\mathrm{Ca}(\mathrm{mg} / \mathrm{L})$ & $37.5 \pm 0.2^{\mathrm{a}}$ & $20.1 \pm 0.1^{b}$ \\
\hline Concentr. Fe $(\mu \mathrm{g} / \mathrm{L})$ & $780.4 \pm 0.1^{\mathrm{a}}$ & $490.3 \pm 0.3^{b}$ \\
\hline Concentr. $\mathrm{Cu}(\mu \mathrm{g} / \mathrm{L})$ & $20.6 \pm 0.6^{b}$ & $40.1 \pm 0.2^{\mathrm{a}}$ \\
\hline Concentr. Ca-oxalate (mg/L) & $14.11 \pm 0.02^{\mathrm{a}}$ & $12.20 \pm 0.06^{b}$ \\
\hline
\end{tabular}

Values are means \pm SD of three measurements and values with different letters $\left({ }^{a, b}\right)$ in a row are statistically different; dm—dry matter; $\mathrm{N}^{*}$ —nitrogen; $\mathrm{HMW}^{* *}$ —high molecular weight; $\mathrm{MMW}^{* * *}$-medium molecular weight; $\mathrm{LMW}^{* * * *}$ - low molecular weight.

Finished beers gave reverse results which could indicate a harsher filtration regime for beer 2 . $\mathrm{rH}$ or redox potential of beer is a measurement of the amount of rapidly reducing substances so-called reductors that are important for the physicochemical but also the sensory stability of the beer. $\mathrm{rH}$ values were approximately the same in both beers and within the normal range (8-12) for this type of beer. Beer 2 showed a statistically significant lower value for bitterness in comparison to beer 1 . This is in accordance with the research Hudson et al. [30] conducted. They too had an increase of bitterness in beer composed from unmalted and malted barley. They presumed this occurred due to the relatively low nitrogen content in the wort, which is the case in our research too. The concentration of vicinal diketones in both beers was below the permissible limit of $0.15 \mathrm{mg} / \mathrm{L}$. Foam stability for beer 1 was lower than the value for beer 2, and both beers were below the minimum $110 \mathrm{~s}$. Since foam stability is influenced by an extremely large number of factors both from raw materials and from the technological process, it is hard to pinpoint why both beers showed reduced foam stability. This could be due to the prolonged proteolytic break during mashing, which is one of the disadvantages of the traditional mashing process with two decoctions. The mashing of beer 1 was done by adding enzyme preparation with proteolytic activity, so it is possible that the contact time of the foam active proteins with the enzyme preparation was too long. The use of wheat in the grist, according to numerous authors, improves the stability of beer foam probably due to the composition of its proteins, glycoproteins, and high molecular weight pentosanes [31-35]. Total nitrogen values were similar for both beers (in beer 1 it was $84.7 \%$ of wort 1 , and in beer 2 it was $82.8 \%$ of wort 2 ). The absolute values for total $\mathrm{N}$ in wort 2 (Table 2) showed a significantly higher concentration than in wort 1 . The difference in total $\mathrm{N}$ between worts was $147 \mathrm{mg} / \mathrm{L}$, while the same difference between bottled beers decreased and was $105 \mathrm{mg} / \mathrm{L}$. This indicated that the removal of total $\mathrm{N}$ during fermentation, aging, and filtration 
is more effective for beer 2 than for beer 1 . HMW $\mathrm{N}$ in beer 1 makes up about $29 \%$ of the total $\mathrm{N}$ (which is significantly more than $20 \%$ considered as normal), while in beer 2 it constitutes $23.3 \%$ of HMW N. Considering the aforementioned effect that maize grits have on nitrogen in malt and beer, it is evident that wheat (especially given its relatively low content of $16 \%$ in the grist) significantly increases the HMW protein fractions in beer. Furthermore, an evident increase in the concentration of MMW proteins in both beers relative to worts occurred. MMW proteins exist in the form of monomers and, during filtration, are more difficult to remove than HMW proteins, so that a greater proportion of the starting material from the wort ends in beer. The concentration of LMW N in both beers was almost below normal ( $\approx 63 \%$ of total $\mathrm{N}$ ). The small difference in the proportion of LMW $\mathrm{N}$ between the two beers is an indicator that wheat addition to grist contributes a certain percentage of nitrogen to the wort. The concentration of total polyphenols in beer 1 and beer 2 was significantly below normal values $(150-200 \mathrm{mg} / \mathrm{L})$. The anthocyanogen concentrations were also significantly below the normal values $(40-70 \mathrm{mg} / \mathrm{L})$ but were significantly higher in beer 1 . The reason for this may be that, although wheat has a low polyphenol content, they are generally present as proanthocyanidins and mostly as prodelfinidins and procyanidins, and to some extent as propelargonidines [36]. These proanthocyanidins are most active as haze inducers in beer $[37,38]$. The concentration of dissolved oxygen, measured one week after bottling, was higher for beer $1,0.21 \mathrm{mg} / \mathrm{L}$. The concentration of calcium in beer is important because of the possibility of Ca-oxalate formation if oxalic acid is present. It is known that calcium and magnesium ions exhibit a certain tendency to penetrate into haze particles [39]. In this research, the concentrations of $\mathrm{Ca}$, Ca-oxalate, and oxalic acid (Table 3) showed not to be a potential problem for colloidal stability, especially since about half of the amount of $\mathrm{Ca}$ ions in both beers are not related to oxalic acid. The concentration of iron ions in both beers was above the maximum permissible concentration in beer $(200 \mu \mathrm{g} / \mathrm{L})$. The concentration of iron in beer 1 was significantly higher $(780 \mu \mathrm{g} / \mathrm{L})$ than allowed, which is unfavorable for colloidal stability. Iron, copper, and zinc ions also exhibit a strong tendency to penetrate into the haze particles. They have a catalytic effect on the oxidation or polymerization of polyphenols (shortened "lag phase" in haze formation), after which they react with proteins. They also promote the oxidation of already present reversible haze into a permanent state [39].

The results for beer haze, immediately after bottling, after forcing test and total haze test, are given in Table 4 . Beer 1 had excellent clarity immediately after bottling ( 0.38 EBC, almost brilliant), while the value for beer 2 was slightly higher $(0.48 \mathrm{EBC}$ units). Both beers were below the limit for brilliant beer (0.5 EBC units). Haze for beer 1, after the forcing test, was on average $1 \mathrm{EBC}$ unit. The results for total haze were not satisfactory for both beers. For light lager beers, stored under normal storage conditions, with the declared colloidal stability of 6 months, the limit for haze after forcing test should not exceed $2.0 \mathrm{EBC}[2]$.

Table 4. Colloidal stability (forcing tests and "total haze" tests) of beers 1 and 2 filled in bottles.

\begin{tabular}{|c|c|c|}
\hline Heading & Beer 1 & Beer 2 \\
\hline \multicolumn{3}{|c|}{ Forcing Test: $24 \mathrm{~h} 0{ }^{\circ} \mathrm{C} / 48 \mathrm{~h} 60^{\circ} \mathrm{C} / 24 \mathrm{~h} 0^{\circ} \mathrm{C}$} \\
\hline Before (EBC unit) & $0.38 \pm 0.03^{b}$ & $0.48 \pm 0.01^{a}$ \\
\hline After (EBC unit) & $1.00 \pm 0.02^{\mathrm{a}}$ & $0.55 \pm 0.05^{b}$ \\
\hline$\Delta(\mathrm{EBC}$ unit $)$ & $0.62 \pm 0.03^{a}$ & $0.07 \pm 0.01^{b}$ \\
\hline \multicolumn{3}{|c|}{ Total Haze Test: $24 \mathrm{~h} 1^{\circ} \mathrm{C} / 120 \mathrm{~h} 60^{\circ} \mathrm{C} / 24 \mathrm{~h} 1^{\circ} \mathrm{C}$} \\
\hline Before (EBC unit) & $0.45 \pm 0.01^{b}$ & $0.51 \pm 0.07^{\mathrm{a}}$ \\
\hline After (EBC unit) & * & $7.21 \pm 0.01$ \\
\hline$\Delta$ (EBC unit) & / & $6.70 \pm 0.03$ \\
\hline
\end{tabular}

The results are mean values \pm SD of two series $2 \times 6$ packages and values with different letters $\left({ }^{a, b}\right)$ in a row are statistically different; ${ }^{*}$ - the instrument could not quantify this value. 
Both experiments regarding the haze induction with chemical agents indicate that the fastest and highest haze formation occurred using the tannic acid. This means that the protein component (HA proteins) in beer represents a greater problem related to the haze formation than polyphenols (especially proteins in beer 1, they showed a higher affinity for tannic acid).

$\mathrm{pH}$ increase (Table 5), is noted for both beers after the forcing test but was more pronounced for beer 2 . Beer viscosity also decreased in both cases, but the decrease was more pronounced for beer 1 .

Table 5. Values of quality indicators for beers 1 and 2 before and after the forcing tests.

\begin{tabular}{ccccc}
\hline \multirow{2}{*}{ Heading } & \multicolumn{2}{c}{ Beer 1 } & Beer 2 \\
\cline { 2 - 5 } & Before & After & Before & After \\
\hline Specific gravity $\left(\mathrm{g} / \mathrm{cm}^{3}\right)$ & $1.00697 \pm 0.00045$ & $1.00689 \pm 0.00034^{\mathrm{b}}$ & $1.00895 \pm 0.00026$ & $1.00902 \pm 0.00039^{\mathrm{a}}$ \\
Viscosity (mPas) & $1.513(1.516)^{*}$ & $1.500(1.510)^{* \mathrm{a}}$ & $1.507(1.468)^{*}$ & $1.500(1.465)^{* \mathrm{~b}}$ \\
$\mathrm{pH}$ & $4.36 \pm 0.03$ & $4.38 \pm 0.02^{\mathrm{b}}$ & $4.50 \pm 0.07$ & $4.57 \pm 0.06^{\mathrm{a}}$ \\
rH & $9.036 \pm 0.012$ & $8.978 \pm 0.011^{\mathrm{b}}$ & $9.225 \pm 0.016$ & $9.175 \pm 0.009^{\mathrm{a}}$ \\
Foam stability (s) & $75.6 \pm 0.5$ & $75.3 \pm 0.2^{\mathrm{b}}$ & $92.8 \pm 0.3$ & $87.9 \pm 0.7^{\mathrm{a}}$ \\
Dissolved oxygen $(\mathrm{mg} / \mathrm{L})$ & $0.21 \pm 0.02$ & $0.20 \pm 0.05^{\mathrm{a}}$ & $0.16 \pm 0.06$ & $0.15 \pm 0.02^{\mathrm{b}}$ \\
\hline
\end{tabular}

The results are mean values \pm SD of two series $2 \times 6$ packages and values with different letters $\left({ }^{(a, b}\right)$ in a row are statistically different; ${ }^{*}=$ calculated to $12 \%$ extract.

A bigger viscosity decrease (Table 5) in beer 1 can be explained by the fact that this beer had a higher starting concentration of colloidal instability precursors, i.e., (HMW and MMW proteins from wheat and a relatively higher proportion of anthocyanogen relative to total polyphenol content). A certain role in this decrease was played by the increased concentration of Fe ions and dissolved $\mathrm{O}_{2}$ (Table 3). It can be assumed that colloidal haze aggregates were formed and bonded HMW proteins and dextrins, removing them from beer and thereby reducing beer's viscosity. Foam stability deteriorated in both beers, but this effect was more pronounced in beer 2 . The concentration of dissolved oxygen decreased in both beers by the same amount. However, given that the concentration of iron in beer 1 was almost twice as higher, and that iron has a catalytic effect on oxidation processes, a greater decrease was expected in it.

The results of the tannic acid (TA) haze induction test results are given in Table 6. Beer 1 was susceptible to haze formation induced with TA. The reason for this is the amino acid composition of the wheat HMW proteins (high proportion of proline and glutamic acid) that contribute to their HA potential. This primarily concerns gliadin, as well as the appearance of homologous, compact regions where these two amino acids appear together and display a strong affinity for reacting with tannic acid and condensed polyphenols in general [40-43].

Table 6. Haze (EBC) results for addition of tannic acid (500 $\mathrm{mg} / \mathrm{L})$ in beer 1, beer 2, and referent beer (300 $\mathrm{mL}$ total volume tann. acid + beer) (incubation at $25^{\circ} \mathrm{C}$ ).

\begin{tabular}{cccc}
\hline \multirow{2}{*}{ Tannic Acid (mL) } & \multicolumn{3}{c}{ Haze (EBC Units) } \\
\cline { 2 - 4 } & Beer 1 & Beer 2 & Ref. Beer \\
\hline 0.0 & $0.44 \pm 0.08^{\mathrm{b}}$ & $0.55 \pm 0.09^{\mathrm{a}}$ & $0.45 \pm 0.02^{\mathrm{b}}$ \\
0.1 & $0.70 \pm 0.02^{\mathrm{b}}$ & $0.92 \pm 0.06^{\mathrm{a}}$ & $0.58 \pm 0.05^{\mathrm{c}}$ \\
0.25 & $1.70 \pm 0.07^{\mathrm{a}}$ & $1.41 \pm 0.05^{\mathrm{b}}$ & $0.93 \pm 0.08^{\mathrm{c}}$ \\
0.50 & $2.56 \pm 0.06^{\mathrm{a}}$ & $2.23 \pm 0.02^{\mathrm{b}}$ & $1.92 \pm 0.04^{\mathrm{c}}$ \\
0.75 & $3.25 \pm 0.05^{\mathrm{a}}$ & $3.05 \pm 0.05^{\mathrm{b}}$ & $2.26 \pm 0.02^{\mathrm{c}}$ \\
1.00 & $4.48 \pm 0.01^{\mathrm{a}}$ & $4.25 \pm 0.08^{\mathrm{b}}$ & $3.68 \pm 0.05^{\mathrm{c}}$ \\
1.25 & $6.54 \pm 0.05^{\mathrm{a}}$ & $5.68 \pm 0.07^{\mathrm{b}}$ & $4.11 \pm 0.00^{\mathrm{c}}$ \\
1.50 & $7.40 \pm 0.12^{\mathrm{a}}$ & $6.05 \pm 0.06^{\mathrm{b}}$ & $5.02 \pm 0.09^{\mathrm{c}}$ \\
1.75 & $*$ & $*$ & $*$ \\
\hline
\end{tabular}

The results are mean values \pm SD of two series $2 \times 6$ packages, and values with different letters $\left.{ }^{(a-c}\right)$ in a row are statistically different; *-the instrument could not quantify this value. 
The results for inducing haze using gliadin (Table 7) showed that beer 2 inclines to a slightly higher haze formation than beer 1, regardless of the absence of gliadin. This can be explained with the higher concentration and nature of total polyphenols originating from malt (beer 2). The referent beer showed the greatest resistance to haze induction with gliadin, which is not surprising since this beer is stabilized with PVPP, which, due to its structure (similar to the structure of peptides (polyproline)), binds phenolic structures with hydrogen bridges, thereby selectively removing polyphenols [42].

Table 7. Haze (EBC) results for addition of gliadin in $200 \mathrm{~mL}$ beer 1, beer 2, and reference beer (incubation at $25^{\circ} \mathrm{C}$ ).

\begin{tabular}{cccc}
\hline Gliadin (mg) & \multicolumn{3}{c}{ Haze (EBC Units) } \\
\cline { 2 - 4 } & Beer 1 & Beer 2 & Ref. Beer \\
\hline 0 & $0.45 \pm 0.03^{\mathrm{a}}$ & $0.54 \pm 0.02^{\mathrm{a}}$ & $0.45 \pm 0.07^{\mathrm{a}}$ \\
1.5 & $0.55 \pm 0.04^{\mathrm{ab}}$ & $0.68 \pm 0.05^{\mathrm{a}}$ & $0.48 \pm 0.02^{\mathrm{b}}$ \\
3.0 & $0.67 \pm 0.02^{\mathrm{b}}$ & $1.00 \pm 0.10^{\mathrm{a}}$ & $0.51 \pm 0.02^{\mathrm{b}}$ \\
5.0 & $0.89 \pm 0.01^{\mathrm{b}}$ & $1.73 \pm 0.07^{\mathrm{a}}$ & $0.81 \pm 0.02^{\mathrm{c}}$ \\
7.5 & $1.01 \pm 0.03^{\mathrm{b}}$ & $1.93 \pm 0.04^{\mathrm{a}}$ & $0.88 \pm 0.02^{\mathrm{c}}$ \\
10.0 & $1.13 \pm 0.02^{\mathrm{b}}$ & $2.48 \pm 0.06^{\mathrm{a}}$ & $1.00 \pm 0.08^{\mathrm{c}}$ \\
15.0 & $4.28 \pm 0.01^{\mathrm{a}}$ & $4.22 \pm 0.11^{\mathrm{b}}$ & $2.54 \pm 0.02^{\mathrm{c}}$ \\
20.0 & $6.51 \pm 0.12^{\mathrm{a}}$ & $5.46 \pm 0.22^{\mathrm{b}}$ & $4.56 \pm 0.04^{\mathrm{c}}$ \\
40.0 & $*$ & $*$ & $12.48 \pm 0.09$ \\
\hline
\end{tabular}

The results are mean values \pm SD of two series $2 \times 6$ packages and values with different letters $\left({ }^{\mathrm{a}-\mathrm{c}}\right)$ in a row are statistically different; ${ }^{*}$ - the instrument could not quantify this value.

Table 8 gives the haze values during 6 months of storage. According to the results from Table 4 , both beers would retain the predicted CSL for 6 months, which, however, was not confirmed by haze measurements during storage (Table 8 ). The haze value of beer 1 increased slowly during the first 60 days, staying below $0.6 \mathrm{EBC}$ units and then rising to about $1 \mathrm{EBC}$ unit and remaining there for about one and a half months (the usual "lag phase" and transition to "increase phase" of haze). After 135 days of storage, haze increases rapidly and enters the opal region, which can be considered as entering the "stationary phase" in which turbidity formation slows its pace and halts. Although the starting haze was higher in beer 2, it showed better resistance to haze increase during the first 90 days of storage. An increase of haze in beer 2 occurred between the 90th and 135th day but was less intensive than in beer 1 . After the 135th day there was a sharp increase of haze, but again less intense than in the case of beer 1 . The haze in beer 1 after the 135th day was close to the haze values after the forcing test (Table 4), while the haze in beer 2 was slightly lower after the forcing test, in comparison to the haze values of the beer 2 after 135 days of storage. Beer 1 had an unsatisfactory clarity for the declared CSL of 6 months, which was consistent with the results of the forcing test, while beer 2 met the requirements for 6 months CSL. The referent beer (colloidal stabile) showed far less haze and fully met the declared CSL, as expected. 
Table 8. Haze for beers 1 and 2 after 0, 30, 60, 90, 135, and 180 days of storage at room temperature.

\begin{tabular}{ccccccc}
\hline \multirow{2}{*}{ Days: } & \multicolumn{7}{c}{ Haze (EBC Unit) } \\
\cline { 2 - 7 } & $\mathbf{0}$ & $\mathbf{3 0}$ & $\mathbf{6 0}$ & $\mathbf{9 0}$ & $\mathbf{1 3 5}$ & $\mathbf{1 8 0}$ \\
\hline Beer 1 & $0.38 \pm 0.05^{\mathrm{e}}$ & $0.49 \pm 0.09^{\mathrm{de}}$ & $0.55 \pm 0.03^{\mathrm{d}}$ & $0.92 \pm 0.11^{\mathrm{c}}$ & $1.01 \pm 0.12^{\mathrm{c}}$ & $2.15 \pm 0.10^{\mathrm{b}}$ \\
Beer 2 & $0.48 \pm 0.06^{\mathrm{f}}$ & $0.56 \pm 0.10^{\mathrm{e}}$ & $0.62 \pm 0.02^{\mathrm{d}}$ & $0.81 \pm 0.04^{\mathrm{c}}$ & $0.79 \pm 0.03^{\mathrm{c}}$ & $1.18 \pm 0.09^{\mathrm{b}}$ \\
Ref. beer & $0.40 \pm 0.05^{\mathrm{c}}$ & $0.42 \pm 0.02^{\mathrm{c}}$ & $0.45 \pm 0.08^{\mathrm{abc}}$ & $0.44 \pm 0.07^{\mathrm{bc}}$ & $0.50 \pm 0.06^{\mathrm{abc}}$ & $0.56 \pm 0.07^{\mathrm{ab}}$ \\
\hline
\end{tabular}

The results are mean values \pm SD of two series $2 \times 6$ packages and values with different letters $\left(^{\mathrm{a}-\mathrm{f}}\right)$ in a row are statistically different.

Table 9 presents the results of certain quality indicators of beer 1 and beer 2 during storage $(0,90$, 135 , and 180 days) at room temperature. It can be observed that the concentrations of dissolved oxygen in beer 1 and beer 2 decreased during storage. The decrease in beer 1 was at first rapid, and after 90 days the decrease was slowed down (accompanied by haze increase), while beer 2 showed a reversed effect. Furthermore, in beer 1 during storage, an increase of specific density, color, and $\mathrm{pH}$ and a decrease in viscosity occurred. These changes are significantly less pronounced in beer 2 , and in the case of viscosity, the drop is barely pronounced. The viscosity of both beers was lower than the recommended values for this type of beer (1.78-1.95 mPa.s, calculated on $12 \%$ of the extract). The increase in color was more pronounced in beer 2 (which was otherwise higher in color than beer 1) but was still within normal limits after 6 months. The $\mathrm{pH}$ was, on average, slightly higher for beer 2 , after bottling and during storage. It can be seen from Table 4 that the $\mathrm{pH}$ increased for beer 2 after the forcing test. $\mathrm{pH}$ values for both beers were not within the recommended limits (4.05-4.30). According to Guyot-Declerck et al. [44] slight changes in $\mathrm{pH}$ can affect the sensory characteristics of the beer. 
Table 9. Values of quality indicators for beers 1 and 2 after 0,90,135, and 180 days of storage at room temperature.

\begin{tabular}{|c|c|c|c|c|c|c|c|c|}
\hline \multirow[b]{2}{*}{ Days: } & \multicolumn{4}{|c|}{ Beer 1} & \multicolumn{4}{|c|}{ Beer 2} \\
\hline & 0 & 90 & 135 & 180 & $\mathbf{0}$ & 90 & 135 & 180 \\
\hline Specific gravity $\left(\mathrm{g} / \mathrm{cm}^{3}\right)$ & $1.00809 \pm$ & $1.00893 \pm$ & $1.00891 \pm$ & $1.00892 \pm$ & $1.0071 \pm$ & $1.00698 \pm$ & $1.00693 \pm$ & $1.00696 \pm$ \\
\hline specitic gravity (g/cm²) & $0.00001^{\mathrm{a}}$ & $0.00001^{\mathrm{a}}$ & $0.00001^{\mathrm{a}}$ & $0.00001^{\mathrm{a}}$ & $0.00001^{a}$ & $0.00001^{\mathrm{a}}$ & $0.00001^{\mathrm{a}}$ & $0.00001^{\mathrm{a}}$ \\
\hline Original extract (\% dm) & $11.96 \pm 0.15^{b}$ & $12.15 \pm 0.12 \mathrm{ab}$ & $12.21 \pm 0.03^{\mathrm{a}}$ & $12.18 \pm 0.02^{\mathrm{a}}$ & $12.16 \pm 0.13^{a}$ & $12.00 \pm 0.05 \mathrm{ab}$ & $11.95 \pm 0.08^{\mathrm{b}}$ & $11.94 \pm 0.10^{b}$ \\
\hline Viscosity (mPas) & $1.513 \pm 0.009^{a}$ & $1.485 \pm 0.010^{\mathrm{ab}}$ & $1.466 \pm 0.007^{b}$ & $1.498 \pm 0.001^{\mathrm{a}}$ & $1.507 \pm 0.001^{a}$ & $1.493 \pm 0.002^{\mathrm{a}}$ & $1.469 \pm 0.006^{\mathrm{a}}$ & $1.502 \pm 0.005^{\mathrm{a}}$ \\
\hline $\mathrm{pH}$ & $4.39 \pm 0.06^{b}$ & $4.46 \pm 0.07^{\mathrm{a}}$ & $4.47 \pm 0.09^{a}$ & $4.45 \pm 0.08^{\mathrm{a}}$ & $4.53 \pm 0.05^{b}$ & $4.57 \pm 0.06^{\mathrm{a}}$ & $4.59 \pm 0.08^{\mathrm{a}}$ & $4.58 \pm 0.03^{a}$ \\
\hline Foam stability (s) & $77.5 \pm 0.5^{b}$ & $78.6 \pm 0.2^{\mathrm{a}}$ & $73.2 \pm 0.7^{c}$ & $66.0 \pm 0.9^{d}$ & $92.8 \pm 0.8^{b}$ & $95.4 \pm 0.8^{\mathrm{a}}$ & $88.0 \pm 0.5^{c}$ & $73.1 \pm 0.2^{d}$ \\
\hline Color (EBC u.) & $6.5 \pm 0.8^{c}$ & $7.6 \pm 0.1^{b}$ & $7.9 \pm 0.2^{a b}$ & $8.2 \pm 0.7$ a & $7.6 \pm 0.3^{c}$ & $8.9 \pm 0.6^{b}$ & $9.2 \pm 0.5^{b}$ & $9.6 \pm 0.7^{a}$ \\
\hline Dissolved oxygen $(\mathrm{mg} / \mathrm{L})$ & $0.21 \pm 0.07^{\mathrm{a}}$ & $0.14 \pm 0.03 b c$ & $0.12 \pm 0.02^{c}$ & $0.11 \pm 0.04^{b}$ & $0.16 \pm 0.00^{\mathrm{a}}$ & $0.13 \pm 0.02^{\mathrm{a}}$ & $0.10 \pm 0.01^{\mathrm{a}}$ & $0.07 \pm 0.03^{\mathrm{a}}$ \\
\hline
\end{tabular}

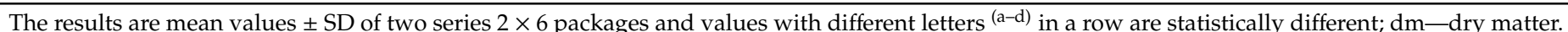




\section{Conclusions}

The results show that the production of light lager beer from grist with $16 \%$ of unmalted wheat is not as efficient in ensuring the colloidal stability, especially regarding haze formation, the main point of this research. This combination could probably be acceptable and would not affect the colloidal stability only if such beer is to be properly stabilized with the silica gel/PVPP combination, which would ensure the removal of HA components-the main cause of haze formation. Although the tested worts and beers had quantitatively similar values for proteins and their fractions (where the values for total proteins are even significantly higher in pure malt beer), based on the results of the conducted research, it can be concluded that beers produced with wheat as unmalted adjunct are inclined toward haze formation mostly because of the nature of wheat proteins. The combination of wheat and maize grits in optimizing the composition of wort with respect to total proteins is not sufficient to compensate for the increased activity of wheat HA protein for turbidity, indicating the importance of the previously mentioned beer stabilization processes. However, wheat should not be a priori ruled out as a substitute for malt in the lager production for it has its advantages, and it would be interesting to carry out the same test where soft white wheat or pure brewing wheat varieties would be used instead of hard, red wheat. It is reasonable to assume that it would significantly reduce the problems related to the colloidal stability of such beers.

Author Contributions: Conceptualization, V.K.; methodology, V.K.; data curation, K.M., J.L.; writing-original draft preparation, K.H.; writing-review and editing, K.H., M.J.; supervision, V.K. All authors have read and agree to the published version of the manuscript.

Funding: This research received no external funding.

Conflicts of Interest: The authors declare no conflict of interest.

\section{References}

1. O'Rourke, T. Predicting Colloidal Stability in Beer. Brew. Int. 2002, 41-42. Available online: http: //www.ibdlearningzone.org.uk/article/show/pdf/495/ (accessed on 23 September 2019).

2. Mélote, L. Measurements of Beer Colloidal Stability. In Proceedings of the XIIIth De Clerck Chair, Louvain-la-Neuve, Belgium, 13-21 September 2008; Available online: https://cdn.uclouvain.be/public/ DeClerckChairMelotte.pdf (accessed on 23 September 2019).

3. Back, W. Ausgewählte Kapitel der Brautechnologie; Fachverlag Hans Carl: Nürnberg, Germany, 2005; pp. $249-265$.

4. Depraetere, A.S.; Delvaux, F.; Coghe, S.; Delvaux, F.R. Wheat variety and barley malt properties: Influence on haze intensity and foam stability of wheat beer. J. Inst. Brew. 2004, 110, 200-206. [CrossRef]

5. Kolbach, P.; Kremkov, C. Zusammensetzung, Schaum und Haltbarkeit der hellen Vollbiere. 1. Mitteilung. Chemische Zusammensetzung und Schaum. Monatsschr. Brau. 1968, 21, 257-269.

6. Kakui, T.; Ishibashi, Y.; Kunihige, Y.; Isoi, A.; Nakatani, K. Application of enzime-linked immunoadsorbent assay to quantitive evaluation of foam-active protein from wheat beer. J. Am. Soc. Brew. Chem. 1999, 57, 151-154. [CrossRef]

7. Steele, T. The original shredding wheat myths. Brew. Tech. 1997, 5, 58-65.

8. Gardner, R.J.; Mc Guinness, J.D. Complex phenols in brewing-A critical survey. Tech. Q. Master Brew. Assoc. Am. 1977, 14, 250-261.

9. Delvaux, F.; Depraetere, A.S.; Delcour, J.A. Characterisation of the colloidal haze in commercial and pilot scale Belgian white beers. J. Inst. Brew. 2012, 106, 221-228. [CrossRef]

10. Taylor, D.G. Brewing ales with malted cereals other than barley. Ferment 2000, 1, 18-20.

11. Delvaux, F.; Gys, W.; Michiels, J.; Delvaux, F.R.; Delcour, J.A. Contribution of wheat and wheat protein fractions to the colloidal haze of wheat beers. J. Am. Soc. Brew. Chem. 2001, 59, 135-140. [CrossRef]

12. Delvaux, F.; Depraetere, S.; Delvaux, F.R.; Delcour, J.A. The ambiguous impact of wheat gluten proteins on the colloidal haze of wheat beers. J. Am. Soc. Brew. Chem. 2003, 61, 63-68. [CrossRef]

13. Pierce, J.S. Adjuncts and their effect on beer quality. In Proceedings of the European Brewery Convention, Madrid, Spain, 10-14 May 1987; IRL Press: Oxford, UK, 1987; pp. 49-60. 
14. Brijs, K.; Delvaux, F.; Gilis, V.; Delcour, J.A. Solubilisation and degradation of wheat gluten proteins by barley malt proteolytic enzymes. J. Inst. Brew. 2002, 108, 348-354. [CrossRef]

15. European Brewery Convention. Analytica, 5th ed.; Fachverlag Hans Carl: D-Nürnberg, Germany, 1998.

16. Middle European Brewing Analysis Commission. Brautechnische Analysenmethoden, 3rd ed.; Band I and Band II; Selbstverlag der MEBAK: Freising-Weihenstephan, Germany, 1997.

17. Siebert, J.K.; Troukhanova, V.N.; Lynn, P.Y. Nature of polyphenol-protein interactions. J. Agric. Food. Chem. 1996, 44, 80-85. [CrossRef]

18. Siebert, K.J.; Carrasco, A.; Lynn, P.Y. Formation of protein polyphenol haze in beverages. J. Agric. Food Chem. 1996, 44, 1997-2005. [CrossRef]

19. Steiner, E.; Becker, T.; Gastl, M. Turbidity and haze formation in beer-Insights and overview. J. Inst. Brew. 2010, 116, 360-368. [CrossRef]

20. Bamfort, C.W. Beer Haze. J. Am. Soc. Brew. Chem. 1999, 57, 81-90. [CrossRef]

21. Unbehend, L.; Unbehend, G.; Lindhauer, M.G. Comparison of the quality of some Croatian and German wheat varieties according to the German standard protocol. Nahrung 2003, 47, 40-44. [CrossRef] [PubMed]

22. Lu, J.; Li, Y. Effects of arabinoxylan solubilization on wort viscosity and filtration when mashing with grist containing wheat and wheat malt. Food Chem. 2006, 98, 164-170. [CrossRef]

23. Hough, J.S.; Briggs, D.E.; Stevens, R.; Young, T.W. Adjuncts, sugars, wort syrups and industrial enzymes. In Malting and Brewing Science; Chapman and Hall: London, UK, 1982; Volume 2, pp. 228-240.

24. Koszyk, P.F.; Lewis, M.J. Unmalted grains as malsters' adjuvant and brewers' adjunct. J. Am. Soc. Brew. Chem. 1976, 35, 77-81. [CrossRef]

25. Outtrup, H. Haze active peptides in beer. In Proceedings of the 22nd European Brewery Convention Congress, Zürich, Switzerland, 20-25 May 1989; IRL Press: Oxford, UK, 1989; pp. 609-616.

26. Shuangqi, T.; Yue, S.; Zhicheng, C.; Yingqi, Y.; Yanbo, W. Functional properties of polyphenols in grains and effects of physicochemical processing on polyphenols-review. J. Food Qual. 2019, 2019, 1-8. [CrossRef]

27. Krstanović, V.; Mastanjević, K.; Nedović, V.; Mastanjević, K. The influence of wheat malt quality on final attenuation limit of wort. Fermentation 2019, 5, 89. [CrossRef]

28. Canales, A.M. Unmalted Grains in Brewing. In Brewing Science; Pollock, J.R.A., Ed.; Academic Press: London, UK, 1987.

29. Hudson, J.R. Institute of Brewing-Analysis Commitee Measurment of Viscosity. J. Inst. Brew. 1970, 70, 341-342. [CrossRef]

30. Hudson, J.R.; MacWilliam, I.C.; Britwistle, S.E. Beer from unmalted barley. Brew. Ind. Res. Found. 1963, 69, 308-309. [CrossRef]

31. Anderson, F.B. Further studies on the foam-stabilizing substances in beer. J. Inst. Brew. 1966, 72, $384-387$. [CrossRef]

32. Asano, K.; Hashimoto, N. Isolation and characterization of foaming proteins of beer. J. Am. Soc. Brew. Chem. 1980, 38, 129-137. [CrossRef]

33. Asano, K.; Hashimoto, N. Characterization of haze-forming proteins of beer and their roles in chill haze formation. J. Am. Soc. Brew. Chem. 1982, 40,147-155. [CrossRef]

34. Lusk, L.; Cronan, C.L.; Chicoye, E.; Goldstein, H. A surface-active fraction isolated from beer. J. Am. Soc. Brew. Chem. 1987, 45, 91-95. [CrossRef]

35. Bamforth, C.W. The foaming properties of beer. J. Inst. Brew. 1985, 91, 370-383. [CrossRef]

36. McCallum, J.A.; Walker, J.R.L. Proanthocyanidins in wheat bran. Cereal. Chem. 1990, 67, 282-285.

37. Mc Murrough, I.; Madigan, D.; Kelly, R.J. The role of flavonoid polyphenols in beer stability. J. Am. Soc. Brew. Chem. 1996, 54, 141-148. [CrossRef]

38. Mc Murrough, I.; Kelly, R.J.; Byrne, J. Effect of the removal of sensitive proteins and proanthocyanidins on the colloidal stability of lager beer. J. Am. Soc. Brew. Chem. 1992, 50, 67-76. [CrossRef]

39. Anger, H.M. Assuring nonbiological stability of beer as an important factor for guaranteeing minimum shelflife. Brauwelt Int. 1996, 14, 142-150.

40. Shewry, P.R.; Field, J.M.; Kirkman, M.A.; Audrey, J.F.; Milfin, B.J. Hordein polypeptide pattern in relation to malting quality and the varietal identification of malted barley grain. J. Inst. Brew. 1980, 86, 138-141. [CrossRef]

41. Siebert, K.J.; Lynn, P.Y. Mechanism of beer colloidal stabilization. J. Am. Soc. Brew. Chem. 1997, 55, 73-78. [CrossRef] 
42. Siebert, K.J.; Lynn, P.Y. Effects of protein-polyphenol ratio on the size of haze particles. J. Am. Soc. Brew. Chem. 1997, 58, 117-123. [CrossRef]

43. Siebert, K.J. Haze formation in beverages. LWT 2006, 39, 987-994. [CrossRef]

44. Guyot-Declerck, C.; François, N.; Ritter, C.; Govaerts, B.; Collin, S. Influence of pH and ageing on beer organoleptic properties. A sensory analysis based on AEDA data. Food Qual Prefer 2005, 16, 157-162. [CrossRef]

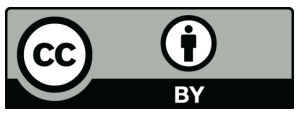

(C) 2020 by the authors. Licensee MDPI, Basel, Switzerland. This article is an open access article distributed under the terms and conditions of the Creative Commons Attribution (CC BY) license (http://creativecommons.org/licenses/by/4.0/). 